Prace Literackie LVII

Wrocław 2017

DOI: $10.19195 / 0079-4767.57 .5$

KAMIL NOLBERT

Uniwersytet Wrocławski

\title{
Dookoła pustki. Widma w villanellach Dariusza Suski
}

\begin{abstract}
Nigdy nie było uczonego, który tak naprawdę, jako uczony, zajmowałby się widmami. Tradycyjny badacz nie wierzy w widma - ani w nic, co można by nazwać wirtualną przestrzenią widmowości. Nigdy nie było uczonego, który, jako taki, nie wierzyłby w ostre rozróżnienie między tym, co realne i tym, co nierealne, tym, co rzeczywiste i tym, co nierzeczywiste, tym, co żywe i tym, co nie-żywe, byciem i nie-byciem (to be or not to be, interpretowane w sposób konwencjonalny), w opozycję między tym, co jest obecne i tym, co nieobecne, na przykład w formie przedmiotowości. Wszystko, co istnieje poza tą opozycją, jest zdaniem uczonego sprawą dyskusyjną, teatralną fikcją, literaturą i spekulacją ${ }^{1}$.
\end{abstract}

Przytaczam ten komentarz, dopisany przez Jacques'a Derridę na marginesie Szekspirowskiego Hamleta, w roli motta, co oznacza, że zamierzam uchylić się w tej chwili od obowiązku omówienia go, podążając jednak śladem zawartej w nim myśli. Postaram się zatem, mówiąc najkrócej, zająć nawiedzającymi poezję Dariusza Suski widmami; ,a jest ich — jak mówi autor Widm Marksa więcej niż jeden: le plus d'un - (nigdy) więcej (niż) jeden"2. Trzeba się z nimi liczyć, szczególnie wtedy, gdy chodzi o widma śmierci, braku, nieistnienia. Ich paradoksalna, bo w istocie niemożliwa do pomyślenia, obecność zakreśla horyzont całej twórczości poetyckiej autora Wszystkich naszych drogich zakopanych. Nie ma w wierszach Suski ważniejszego i boleśniejszego doświadczenia egzystencjalnego niż obcowanie ze śmiercią, z duchami powracającymi z przeszłości;

1 J. Derrida, Widma Marksa. Stan dlugu, praca żałoby i nowa Międzynarodówka, przeł. T. Zatuski, Warszawa 2016, s. 32-33.

2 Ibidem, s. 16. 
inaczej, poza nimi, bez nich — nie da się myśleć ani życia jako takiego, ani poezji. Pojawiające się po raz pierwszy w Duchach dni villanelle jak w soczewce skupiają w sobie wszystkie te kwestie: służą poecie, z jednej strony, do powiedzenia czegoś na temat nawiedzających go zjaw, z drugiej strony — już same w sobie są w jakimś sensie nawiedzone; słychać w nich mniej lub bardziej utajone głosy innych poetów, zupełnie jakby pozostawili po sobie ślady na metaforycznym ciele wiersza-villanelli i jakby przyjęcie tego spadku, za jaki uznać można wzorzec gatunkowy, oznaczało konieczność spłaty pewnego długu wobec nich ${ }^{3}$.

\section{Dziedziczenie albo genealogia widm}

Tropy, ślady prowadzące do swoich literackich poprzedników Suska podsuwa czytelnikom chętnie, dlatego też wskazanie poetów, którzy w ten czy inny sposób wywierali na niego wpływ, nie sprawiało krytykom z reguły większych trudności; wielokrotnie, jak najsłuszniej, pisano o pewnej wspólnocie wyobraźni, jaka łączy autora Czystej ziemi z Jarosławem Markiem Rymkiewiczem i Bolesławem Leśmianem ${ }^{4}$; innym razem zwracano uwagę na umiejętne wykorzystanie i przetworzenie przez poetę tradycji literatury wanitatywnej, skądinąd bardzo bogatej, a obejmującej autorów starożytnych, średniowiecznych czy barokowych ${ }^{5}$. Duchy dni repertuar intertekstualnych odniesień, a chciałoby się powiedzieć: śladów nawiedzeń (w) poezji Suski, rozszerzają m.in. o wiersze Paula Celana, Wystana H. Audena oraz Dylana Thomasa (ale także ich tłumacza, a w każdym razie jednego z nich — Stanisława Barańczaka $\left.{ }^{6}\right)$.

3 Jeśli w poniższych rozważaniach skupiam się przede wszystkim na villanelli, to dlatego, że pojawia się ona w twórczości autora Czystej ziemi bodaj w tym samym momencie, w którym poeta coraz bardziej zaczyna się interesować tym, co abstrakcyjne, czego istnienie wydaje się jednocześnie i pewne, i wątpliwe. Tej zbieżności nie chcę tu sprowadzać do prostej relacji wynikania, nie wiadomo bowiem $\mathrm{w}$ istocie, co z czego miałoby wynikać, zwracam jedynie uwagę na istnienie pewnej między nimi zależności. Tu i ówdzie pojawiają się, rzecz jasna, odniesienia do innych utworów poety, a dzieje się to z tego względu, że choć villanellę uznać można za szczególnie uprzywilejowaną, kiedy chodzi o mówienie o pustce, śmierci, braku w poezji Suski, to jednak większość poniższych rozpoznań z powodzeniem mogłaby objąć właściwie cały dorobek autora Wszystkich naszych drogich zakopanych.

4 Zob. M. Hapke, ,Napatrzyliśmy się na znikanie” - parę uwag o nieistnieniu w wierszach Dariusza Suski, [w:] Świat na językach, red. P. Śliwiński, Poznań 2015, s. 117-129; M. Jaworski, Formy nieistnienia. O wierszach Dariusza Suski, [w:] Świat na językach ..., s. 131-139; B. Mytych, Przywracanie wiary w śmierć, „FA-art” 2004, nr 2, s. 64-65; J. Sobolewska, Martwe pod nami, „Odra” 2004, nr 10, s. 108-110; K. Maliszewski, „Nie śmierć, ale jej przezwyciężenie”, [w:] idem, Rozproszone głosy. Notatki krytyka, Warszawa 2006, s. 182-186.

5 A. Świeściak, Alegorie. Dariusz Suska, [w:] eadem, Melancholia w poezji polskiej po 1989 roku, Kraków 2010, s. 254-273.

${ }^{6}$ Sprawa z Barańczakiem wymagałaby dłuższej analizy, bo - jak się wydaje — nie dotyczy tylko interesującej mnie tu villanelli, zwracali na to uwagę m.in. Marcin Jaworski (op. cit.) oraz Paweł Mackiewicz (Wieje groza w powiecie, [w:] idem, Pisane osobno. O poezji polskiej lat pierwszych, Poznań 2010, s. 219-225). 
Nie chcąc wchodzić w szczegółowe rozważania na temat sposobów rozumienia tradycji literackiej, można powiedzieć, pozostając na dość wysokim poziomie ogólności, że gest przejęcia wzorców określonych gatunków, pewnej wrażliwości poetyckiej czy wyczulenia na takie, a nie inne tematy zasadniczo nie wyczerpuje się ani w formule bezinteresowności, ani działań uznawanych za, ściśle rzecz biorąc, pokojowe. Szczególnie w sytuacji, w której chciałoby się rozpatrywać je, po Bloomowsku, w kategoriach swoistego agonu, świadomej walki o poetycką niezależność ${ }^{7}$. Posłużenie się retoryką bliższą filozofii Derridy i mówienie o formie nawiedzenia nie do końca rozwiązuje problem, bo choć źródło i kierunek relacji mogą się różnić, nadal mielibyśmy do czynienia z rodzajem symbolicznej przemocy. Interesujące wydaje się natomiast to, co francuski filozof ma do powiedzenia na temat dziedzictwa i dziedziczenia ${ }^{8}$.

Dziedzictwo nie jest nigdy czymś da ny m, zawsze jest pewnym zadaniem. To, że zawsze pozostaje ono przed nami, jest równie bezsporne, jak to, że jesteśmy spadkobiercami - nawet zanim jeszcze podejmiemy decyzję o przyjęciu lub odrzuceniu spadku — i jak wszyscy spadkobiercy, jesteśmy pogrążeni w żałobie. [...] To, że jesteśmy spadkobiercami, nie oznacza, że mamy lub dostajemy to czy tamto, jakieś dziedzictwo, które pewnego dnia wzbogaci nas o to czy o tamto, ale że bycie tego, czym jesteśmy, jest przede wszystkim dziedziczeniem, czy nam się to podoba i czy o tym w ogóle wiemy, czy nie?

Derrida nieprzypadkowo wykorzystuje później Hölderlina, by odpowiedzieć na pytanie, jak należałoby oddać sprawiedliwość owemu byciu jako dziedzictwu, a mianowicie — dając świadectwo ${ }^{10}$. Nieprzypadkowo dlatego, że obecność autora Chleba $i$ wina pozwala Derridzie na przywołanie ducha Heideggera, do którego wyraźnie nawiązuje i wobec którego sam pozostaje zobowiązany. Skoro dziedziczenie jest pewnym zadaniem do wykonania, nie może, tak w przypadku Suski, jak każdym innym, oznaczać jedynie przyjęcia bądź odrzucenia literackiej schedy po poprzednikach.

W poezji autora Czystej ziemi interesuje mnie coś, co chciałbym nazwać dziedziczeniem lub dziedzictwem śmierci, przejawiającym się w poety byciu w nieustannej, niedającej się przepracować żałobie. To, co można uznać za tak pojęte dziedzictwo (dotyczy to także śmierci), nie jest bytem, nie jest obecne, ale daje się myśleć wyłącznie jako wydarzenie, jako coś, co się komuś lub czemuś przydarza, a zatem — nie należy do teraźniejszości i zawsze jest tym, co nadchodzi,

${ }^{7}$ H. Bloom, Lęk przed wpływem, przeł. A. Bielik-Robson, M. Szuster, Kraków 2002.

${ }^{8}$ Projektowany tutaj, a zapośredniczony w filozofii Derridy, sposób rozumienia tradycji w ogóle odbiega od klasycznych ujęć, jakie w poprzednim wieku proponowali tak krytycy, jak teoretycy poezji, ale ze względu na dalsze rozważania to on wydaje się najbardziej odpowiadać interesującemu mnie problemowi. XX-wieczne dyskusje na temat możliwych sposobów rozumienia tradycji przedstawia J. Tabaszewska (Poetyki pamięci. Wspótczesna poezja wobec tradycji i pamięci, Warszawa 2016, s. 25-113).

9 Ibidem, s. 97-98.

10 Ibidem. Zob. także M. Heidegger, Hölderlin i istota poezji, przeł. K. Michalski, [w:] Teoria badań literackich za granica. Antologia, red. S. Skwarczyńska, t. 2, Kraków 1981, s. 185-199. 
lub tym, co minęło. Autor Całej w piachu nie próbuje zresztą w swoich tekstach stanąć ze śmiercią twarzą w twarz, rozmija się z nią również w tym sensie, że jego poetycka tanatologia $\mathrm{w}$ większości przypadków ma swoje źródło w doświadczeniach dzieciństwa (przeżywanego niejako podwójnie: własnego i córki). Wszechobecność śmierci i jej znaków nie równa się, rzecz jasna, oczywistości ani zrozumiałości. To, że czeka ona każdego, nie ulega wątpliwości i nie podlega negocjacji. Bohaterowie wierszy Suski starają się ją zresztą oswoić, najczęściej zadając ją słabszym od siebie. Przewijający się przez niezliczoną liczbę wierszy korowód zabijanych zwierząt (kotów, kiełbi, pszczół, jaskółek itd.), ofiar uprawianych przez młodych chłopców ćwiczeń w śmierci ${ }^{11}$, nie odsyła jedynie do braku w sensie materialnym, fizycznym; konstruowane przez poetę pejzaże złożone z rozkładających się przedmiotów, te wszystkie rzędy ,gierkowskich bloków”"12, „obrazy / przypadkowych ławek, blaszanych śmietników / pod zleżałym śniegiem dziur w jezdni, chodników” (Światto, Ś 9), choć są jak najbardziej konkretne, wręcz namacalne, przejawiają spory potencjał uniwersalności. W jakimś sensie zapowiadają zwrot poety ku temu, co przeziera z drugiej strony, bo właśnie wtedy, kiedy pochłania go coraz bardziej, za Leśmianem ${ }^{13}$, pustka, a mówiąc Derridą, „obecna nieobecność, to bycie-tu tego, czego nie ma, lub tego, co odeszło" ${ }^{14}$, jego wiersze wydają się najciekawsze. Tak pojęte dziedzictwo (śmierci), któremu należy dać świadectwo, stanowić musi jednocześnie zobowiązanie wobec nieskończenie Innego: „chciałbym — mówił Derrida — w końcu nauczyć (się) żyć”15. Projektowany w ten sposób rodzaj odpowiedzialności wykracza poza klasycznie rozumianą czasowość, poza postrzeganie czasu jako następstwa zdarzeń; u Suski dałoby się przyjęcie podobnego punktu widzenia zilustrować tym, że oprócz nawiedzających go duchów osób dawno już zmarłych pojawiają się również ci, „,co nie zdołali / dowiedzieć się, że żyją (zdumiewa mnie to), zmarli / zanim mogli porzucić bądź powziąć nadzieję" (Sektor niemowląt: ci co nie zdołali, Wndz 41) ${ }^{16}$.

Niewspółczesność, a zarazem nieuchronność śmierci, niemożliwość pogodzenia się z nią i zrozumienia jej sprawiają, że powraca w postaci widma, straszy, staje się źródłem obsesji. Rozchwianie związku człowieka z czasem, tak istotne dla Derridy koncepcji widmontologii, z jednej strony w ogóle umożliwia — przez

${ }^{11} \mathrm{Na}$ temat śmierci zwierząt oraz, by tak rzec, „śmiercionośności” dziecka w poezji Suski pisała K. Kuczyńska-Koschany, Śmierć - a zwłaszcza śmierć zwierzęcia jako doświadczenie dziecka - w wierszach Dariusza Suski, [w:] Świat na językach..., s. 109-116.

12 D. Suska, Czysta ziemia (1998-2008), Wrocław 2008, s. 17. Jeśli nie zaznaczono inaczej, wszystkie dalsze odniesienia do utworów Suski w tekście głównym podaję za powyższym wydaniem, odnotowując $\mathrm{w}$ nawiasie tytuł wiersza, skrót odsyłający do tytułu tomu oraz stronę. Ś Światło, Wndz - Wszyscy nasi drodzy zakopani, Cwp - Cała w piachu.

13 Por. M. Hapke, op. cit.

14 J. Derrida, op. cit., s. 24.

15 Ibidem, s. 11.

16 A. Marzec, Widmontologia. Teoria filozoficzna i praktyka artystyczna ponowoczesności, Warszawa 2015, s. 229-250. 
osłabienie gmachu zachodniej metafizyki — zjawienie się widma; z drugiej strony zmusza poznający podmiot do odnalezienia się w nowej, pełnej śladów i pęknięć rzeczywistości. Przekonanie o tym, że czas został wytrącony ze swoich kolein, o tym, że jest on, jak mówił Hamlet, „kością, wyłamaną w stawie” ${ }^{17}$, to typowe doświadczenie nowoczesności, które - jak twierdzi Tadeusz Sławek — słychać w ustach Szekspirowskiego księcia, u Nietzschego i Rilkego ${ }^{18}$, ale również, można dodać, w wielokrotnie omawianej dziewiątej tezie Benjamina o pojęciu historii $^{19}$. Melancholik-Suska komentuje rzecz następująco:

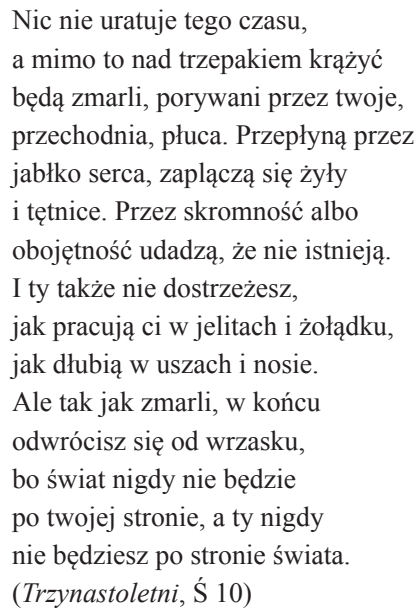

Dziedziczona przez poetę tradycja villanelli jest więc, jako się rzekło, swoistym zobowiązaniem wobec pewnej generacji widm (Auden — Thomas - Bishop Barańczak), widm nieustannie nawiedzających jego utwory. Próba rozstrzygnięcia, czy wybór tego akurat gatunku należałoby uznać za naturalną konsekwencję poetyckiego projektu Suski, nie wydaje się z tego względu ani konieczna, ani celowa ${ }^{20}$.

17 W. Shakespeare, Hamlet, ksiażę Danii, przeł. S. Barańczak, Poznań 1990, s. 52.

18 T. Sławek, Ratujace niebezpieczeństwo postsekularyzmu. Stowo wstęne, [w:] Drzewo poznania. Postsekularyzm w przektadach $i$ komentarzach, red. P. Bogalecki, A. Mitek-Dziemba, Katowice 2012. Giorgio Agamben zwraca uwagę, za Nietzschem, właśnie na „bycie nie na czasie” i przekonanie o przyjściu nie w porę jako na najważniejszą cechę już nie nowoczesności, ale każdej współczesności i faktu bycia komuś lub czemuś „współczesnym”: „Współczesność jest zatem szczególnego rodzaju związkiem z własnym czasem: należy do niego, lecz zarazem się od niego oddala. Mówiąc dokładniej, jest ona takim związkiem z czasem, który do niego należy poprzez przesunięcie faz i anachronizm" (Czym jest współczesność, [w:] idem, Nagość, przeł. K. Żaboklicki, Warszawa 2010, s. 17).

19 W. Benjamin, O pojęciu historii, przeł. A. Lipszyc, [w:] idem, Konstelacje. Wybór tekstów, przeł. A. Lipszyc, A. Wołkowicz, wstępem opatrzył A. Lipszyc, Kraków 2012, s. 316.

${ }^{20} \mathrm{~W}$ ten sposób, nie kryjąc przy tym swego zdziwienia, że poeta dopiero w Duchach dni sięga po villanellę, pisał o pojawieniu się nowej formy w wierszach Suski Paweł Kozioł. Trudno powiedzieć, czy wybór ten, jak sugeruje krytyk, jest w istocie tak oczywisty, jakim chciałby go on widzieć. Przywiązywanie wagi do warstwy rytmicznej wierszy mogło, choć wcale nie musiało, prowadzić do przejęcia akurat tego gatunku (zob. P. Kozioł, Dariusz Suska, ,Duchy dni ”, „Dwutygodnik” 2012, marzec, http://www.dwutygodnik.com/artykul/3259-dariusz-suska-duchy-dni.html [dostęp: 2.02.2017]). 
Suska bowiem wcześniej jak najlepiej obchodził się bez niej, choć już wtedy język jego poezji zwracał uwagę dbałością o warstwę brzmieniową, a rytm oraz rym, zapewniając jego wierszom wyraźną stabilność, służyły poecie do porządkowania otaczającego świata. Tymczasem villanella — o tym trzeba pamiętać - niejako na przekór pewności, jaką obwarowanie jej precyzyjnymi wymogami formalnymi mogłoby sugerować, w swojej historii rzadko kiedy służyła do harmonizacji świata zewnętrznego; jej elegancja, zawierająca się w powtarzalności i różnicy, skłaniała raczej do mnożenia sprzeczności, gry paradoksem, a więc użycia środków szczególnie dobrze sprawdzających się w poezji egzystencjalno-metafizycznej ${ }^{21}$.

Nieprzypadkowo rozważania dotyczące doświadczania śmierci oraz czasu stanowiły punkt wyjścia moich rozważań; to bowiem wokół ich nieusuwalności, ich ścisłego związku krąży większość najważniejszych utworów Suski, jak klasycznych już dzisiaj villanelli Audena, Thomasa i Bishop. Bezwzględność upływu czasu historycznego i biologicznego (w Ale nie moge $e^{22}$ Audena), katalog strat i świadomość wydziedziczenia, bycia poza właściwym sobie miejscem (Ta jedna $s z t u k a^{23}$ Bishop) i próba oddania paradoksalnego, bo jednocześnie naturalnego i sprzecznego z ludzkimi dążeniami, związku pomiędzy życiem i śmiercią u Thomasa (Nie wchodź tagodnie do tej dobrej nocy ${ }^{24}$ ) — wszystkie te wątki wracają niejako echem u Suski, jako pozostawione na metaforycznym ciele villanelli ślady. Niech Powietrze, utwór otwierający Duchy dni, służy za przykład:

Pamiętasz, za stawami, w najjaśniejszy dzień,

który był wymysłem tak jak my nie raz

paliliśmy czasem paliliśmy czas,

Który jest wymysłem, oparci o cień

nic nie rozumiejąc $\mathrm{z}$ tej nieprzeźroczystej

pamiętasz, za stawami, w najjaśniejszy dzień

Mgły po słońcu nad wodą w niecce za boiskiem

po radzieckiej minie kryjąc się, aż strach

całowałaś mnie czasem całowałaś czas

Rzeczy są wymysłem, pięć różowych cięć

na nikłych ramionach, ten tak rzeczywisty

pamiętasz, za stawami, w najjaśniejszy dzień

${ }^{21}$ Por. A. Sosnowski, Skarb kibica (,foremki” x5), [w:] idem, „Najryzykowniej”, Wrocław 2007, s. 116-135. Uwagi Sosnowskiego dobrze oddają istotę formy: „na pierwszy rzut oka »łańcuch DNA« vilanelli może się wydać dość pokrętny, ale przy bliższych oględzinach uderza lekkość efektu całej kompozycji — owe dwa aspekty, prostota i trudność, wyznaczają paradoksalną naturę formy i przesądzają o jej bardzo szerokiej skali tematycznej: vilanella może w zupełności zdać się na melodyjną eteryczność [...], potrafi też udźwignąć treść niemal przygniatająco ważką, gdyż drobny ścieg rymów i refren zawsze będą działały odciążająco, przybliżając nasz wiersz do piosenki” (s. 131).

22 W.H. Auden, 44 wiersze, wybór, przekład, wstęp i oprac. S. Barańczak, Kraków 1994, s. 91.

23 E. Bishop, 33 wiersze, wybór, przekład, wstęp i oprac. S. Barańczak, Kraków 1995, s. 143.

24 D. Thomas, Wiersze wybrane, przeł. S. Barańczak, Kraków 1974, s. 183. 


\section{Sygnał będzie boleć, będzie się odpryskiem tak nierzeczywistym, choć nie jest to sen całowałaś mnie czasem zrywając się z krzykiem \\ Z powodu os w trawie w najjaśniejszy dzień nadto rzeczywiści byliśmy wymysłem $\mathrm{z}$ myślą, że jesteśmy biegnąc $\mathrm{w}$ sen po snach pamiętasz, za stawami paliliśmy czas ${ }^{25}$.}

Tytułowe „powietrze”, podobnie jak wyłaniającą się zza wersu refrenicznego mgłę, jeśli tylko przypomnieć duchy zmarłych porywanych przez nasze płuca i zapowiedzieć dziecko przemieszczające się w powietrzu, uznać należy za elementy znaczące. Interpretacyjnie istotniejsze, odchodząc jednak od widmowo-powietrznej metaforyki, wydaje się tutaj pewnego rodzaju zawęźlenie dwóch perspektyw czasowych, ich nieustanne przenikanie się. A mówiąc inaczej — ich niezgodność, niewczesność: otwierający villanellę zwrot do jakiegoś lirycznego „ty”, mający sens jedynie w teraźniejszości, z konieczności już minionej, nie daje się pogodzić z czasem definitywnie przeszłym, którego dotyczyć musi przywoływane wspomnienie. Aporia dotyczy tu nie tylko czasu, zarazem rzeczywistego i nierzeczywistego, fikcyjnego, będącego, jak mówi poeta, wymysłem, ale również — a niewykluczone, że przede wszystkim — naszego istnienia („Pamiętasz, za stawami, w najjaśniejszy dzień, / który był wymysłem tak jak my nie raz”) i realności wspomnień. A idąc nawet dalej - możliwości pamięci. Ten ostatni wątek powracać będzie, na przekór panoszącej się i zbierającej coraz większe żniwa śmierci, oprócz villanelli także w innych utworach, za każdym razem przywoływany, niejako na podobieństwo charakterystycznego dla niej wersu refrenicznego, owym „pamiętasz” (na przykład w wierszach Pamiętasz, za stawami, DD 7; Napatrzyliśmy się na znikanie, DD 16; Te zabawy, DD 25; Topienie się w stawie, DD 53; Złodzieje kukurydzy, DD 54).

Ale pytanie Suski ma w gruncie rzeczy charakter retoryczny, próba nawiązania kontaktu przypomina tu niemożliwą rozmowę z duchem, widmem (z) przeszłości, które nie z każdym — jak widmo ojca Hamleta — chce rozmawiać lub do którego nie każdy potrafi odpowiednio przemówić, co niekoniecznie oznacza to samo. Kończące jedną z villanelli pytanie: „Jak to, nie pamiętasz?” (Pamiętasz za stawami, DD 7) boleśnie wyraża fiasko usilnie podejmowanych prób porozumienia z owym nieskończenie Innym (jego głęboko skrywaną, tłumioną, niewyrażalną tajemnicę najpełniej oddaje Barańczakowa villanella Płakała w nocy, ale nie jej płacz go zbudzi ${ }^{26}$ ). Ani śmierć, ani czas nie udzielą na pytanie o pamięć żadnej odpowiedzi. I to być może w tym sensie Auden nawiedza Suskę, ze swoim gorzkim „time will say nothing but I told you so”, innym razem zaś — w Trenie

25 D. Suska, Duchy dni, Wrocław 2009, s. 5. Paginacje podaję w tekście jako DD ze wskazaniem tytułu wiersza oraz strony.

26 J. Dembińska-Pawelec, Stanisław Barańczak: Płakała w nocy, ale nie jej płacz go zbudzit, [w:] eadem, Villanella: od anonima do Barańczaka, Katowice 2006, s. 198-210. 
(DD 33), świetnej parafrazie Audenowskiej elegii Funeral Blues, w której Suska pisze: „Uwięzić czas w czarnej dziurze i wszystkie wiersze o śmierci. / Nie powinniśmy ich pisać. Nie znaczą nic, nie znaczą, / Jeżeli śmierci nie ma. Jeżeli jest, to tak samo". Pilnie odbierane przez bohaterów Suski, acz „pospieszne lekcje” znikania (Napatrzyliśmy się na znikanie, DD 16) ani nie pozwalają na wyjście z sygnalizowanego impasu, a więc na znalezienie odpowiedniej formuły na mówienie o śmierci, braku, pustce, ani nie zapewniają ukojenia, potęgują jedynie niepewność, lęk oraz niezgodę na zastaną rzeczywistość.

\section{Zakłócenie rytmu}

W przypadku villanelli autora Duchów dni do głosu dochodzi jeszcze jedna, bardzo istotna tendencja. Poeta zakłóca i podważa pewność, którą obiecuje każdemu użytkownikowi tak precyzyjna i stabilna forma. Jeśli nie sposób skwitować dwoma słowami niewątpliwej elegancji jego villanelli (to zresztą jej znak rozpoznawczy jako gatunku), to dzieje się tak przede wszystkim dlatego, że poeta — dla swoich celów - świadomie odstępuje od realizacji założeń wzorca. Próżno szukać w jego bogatym dorobku choć jednego utworu, który przestrzegałby wszystkich sześciu zasad kompozycji villanelli. Historyk gatunku mógłby powiedzieć, że Suska sytuuje się w cokolwiek licznym szeregu poetów-reformatorów, kuszonych wprawdzie przez ową „eteryczną melodyjność”, by posłużyć się słowami Sosnowskiego, ale mających jednocześnie nieco mniej rygorystyczne podejście do stawianych przez wzorzec wymogów. W tym sensie autor Duchów dni byłby kontynuatorem tradycji reformatorskiej, której realizacje określa się mianem tzw. free form ${ }^{27}$. Zaliczałby się więc do poetów uznających powtarzalność za istotę gatunku, wprowadzających jednak do własnych utworów różne innowacje: czy to przez dodawanie kolejnych tercyn, czy zróżnicowanie długości poszczególnych wersów, a w konsekwencji — rezygnację z klasycznie pojętego metrum. Uchylam się od próby katalogowania zmian, jakie poeta proponuje, bo nie to interesuje mnie najbardziej (powiem jedynie, że najłatwiej było mu rozstać się z gęstą i ściśle uporządkowaną siatką rymów, co widać już w cytowanym utworze Powietrze).

Niepełny, niejako niedokończony charakter villanelli u Suski ma, jak sądzę, określone konsekwencje interpretacyjne. Stanowi nieprzypadkowy gest zakłócenia jej wewnętrznego rytmu, wyraz buntu przeciw poetyckiemu zamknięciu, pewnego rodzaju znaczeniowej samowystarczalności villanelli. Rozspójnienie, do jakiego w tym wypadku dochodzi, pozbawienie gatunku przyrodzonej mu, wewnętrznej stabilności może być interpretowane jako próba ucieczki od mocnego, metafizycznego myślenia tak początku (niezależnie od tego, czy chodzi o Boga, czy światło ludzkiego rozumu), jak końca (a więc śmierci) ${ }^{28}$, a zarazem — jako

27 J. Dembińska-Pawelec, Villanella: od anonima do Barańczaka..., s. 136-144.

28 A. Zawadzki, Literatura a myśl staba, Kraków 2009, s. 61-62. 
zbliżenie się przez poetę do tradycji ujmowania i bycia, i śmierci, jak powiedziałby Vattimo, w kategoriach „myśli słabej”29. Poeta unika prób powiedzenia o śmierci czegoś ostatecznego (stąd być może konieczność ponawiania wysiłków), nie stara się zamknąć jej w okrągłej formule (a w każdym razie nie bez ironicznego nawiasu bądź natychmiastowego zaprzeczenia tego, co przed chwilą powiedział); mnoży sprzeczności, błądzi w labiryntach istnienia i nie-istnienia, z których nie jest w stanie go wyprowadzić ani Leśmian, ani niewinne i naiwne dziecko, do którego często się zwraca i którego punkt widzenia — lub wyobrażenie o nim (tak skonstruowana jest przecież Cała $w$ piachu) — przenosi niekiedy do wierszy:

jest śmierć, której nie ma, bo w jej ciemnych brzegach

Mieszka wszystko, jak zniknie, zniknie śmierć nie ty, a ciemność znaczy tyle, że wyrosły drzewa, pomyślałem mnie nie ma, skoro ty usnęłaś

Obudziłem się we śnie na czerwonych światłach, ten sen od dzieciństwa za dalekie miasto w nim śmierć, której nie ma, bo w jej ciemnych brzegach

Nie ma ciebie szczęśliwie tylko puste pasma

(Pomyślatem mnie nie ma, DD 30)

Można powiedzieć, że w pełni świadomie, rozszczelniając villanellę i tworząc w niej luki, puste miejsca, Suska sam zaprasza do nich widma, duchy. Tak mogłoby być z Annelore Schwartz, o której pisze: „Jej nie było, dlatego widzę ją. Dziewczynkę / w sukieneczce w maki, czarnych złych lakierkach / mówiła po niemiecku, że świat nie ma serca" (Annelore Schwartz, DD 14). I podobnie, chociaż to już przykład nie z villanelli, w Autobiografii z roku 2007, w której pojawiający się na końcu wiersza chłopiec, owo „stare dziecko”, istnieje i nie istnieje, „Jest i nie jest” i — jak zjawa — „przemieszcza się w powietrzu” (DD 40).

Zakłócenie rytmu villanelli widać najwyraźniej w replice, której autor $C z y$ stej ziemi udzielił Dylanowi Thomasowi oraz jego mistrzowskiej villanelli Do not go gentle into that good night:

Wyjdź jak najciszej z tej okropnej nocy

Najlepiej boso, z odjętym językiem

Nie budź jej, nie pisz, odgrzeb z kołder, kocy

Dni nie. To puste na rynnach się złoci

Czas nie. To puste żyłami się toczy

Jak w tych, co weszli do najczystszej nocy.

${ }^{29}$ G. Vattimo, Dialektyka, różnica, myśl słaba, przeł. M. Surma-Gawłowska, A. Zawadzki, [w:] Myśl mocna, myśl słaba. Hermeneutyka włoska od połowy XX wieku. Antologia tekstów, wybór, przekład i oprac. M. Surma-Gawłowska, A. Zawadzki, Kraków 2015, s. 133-148. W tym sensie, w jakim Vattimo powiada, że myślenie bycia możliwe jest już tylko w postaci „myśli słabej”, nie jako obecności, ale wydarzenia się bycia, wyraźnie widać, jak wiele wspólnych punktów łączy jego koncepcję z Derridowską widmontologią. Por. uwagi na ten temat w pracy Andrzeja Marca (op. cit.). 
Nie idź za nikim, nikt nie obudzi śniących

Pisk po imieniu w nieludzkiej oddali

Dni nie. Nie będzie. Ani nawet nocy.

To tylko puste dachy z dykty złoci,

Ściany z powietrza to ściany ze stali.

Wyciągnij wnioski z bezlitosnej nocy

Wyjdź ze stuletnich zetlałych przeźroczy

$\mathrm{Na}$ światło dzienne. Cokolwiek to znaczy.

(Wyjdź jak najciszej z tej okropnej nocy, DD 37)

Rzut oka na układ stroficzny pozwala stwierdzić, że w odpowiedzi na tę bodaj najsłynniejszą XX-wieczną villanellę Susce zabrakło czterech wersów i właściwego ich podziału, by w ogóle można było mówić o spełnieniu najprostszego wymogu, jaki stawia forma. Ale poeta stara się rekompensować ten brak dość gęstą siatką rymów, odgrywających tu rolę namiastki ścisłego rymowania $a b a$, oraz czterokrotnym powtórzeniem „,nocy” w wygłosie wersów. Mistrzostwo Do not go gentle into that good night, jak podkreślają krytycy, ma swoje źródło w wirtuozerskiej grze przeciwieństw i paradoksów, ujętej w precyzyjną formę villanelli ${ }^{30}$. Nie sposób czynić zarzutu poecie z tego, że nie kopiuje dokładnie wzorca, że nie odpowiada villanellą na villanellę, skoro uzyskany efekt wydaje się równie interesujący. Znów jednak istotniejszy okazuje się inny aspekt wiersza: $\mathrm{z}$ daleka dochodzą nas głosy już nie jakiegoś jednego ducha, widma, ale przynajmniej kilku. Na pytanie, skąd i dlaczego przychodzą, nie sposób udzielić prostej odpowiedzi; można się zastanawiać, czy ujawnienie się śladów ich dawnej obecności, ich ponowne dojście do głosu należy rozumieć jako przejaw „gościnności” Suski czy wtargnięcia widm-intruzów. Gościnność jako taka jawi się już zawsze jako głęboko dwuznaczna: jeśli gospodarz nie chce stawiać przybyszowi warunków, zostaje zmuszony do zamilknięcia i wyrzeczenia się samego siebie; jeśli natomiast przyjęcie w gościnę obcego, nieskończenie Innego poprzedzone zostaje szeregiem zastrzeżeń, przybiera formę konwencji, sztywnych norm i zakazów, dochodzi do odrzucenia gościnności na rzecz swoistej relacji władzy ${ }^{31}$. Interesujące mnie pęknięcie, owo zakłócenie słychać najlepiej w trzecim wersie. W pierwszej chwili otwierający tę linijkę imperatyw „Nie budź jej” z powodzeniem czytamy

30 J. Dembińska-Pawelec, Villanella: od anonima do Barańczaka..., s. 92-99.

31 A. Marzec, op. cit., s. 133-146. Nierozwiązywalność, paradoksalność fenomenu gościnności była dla Jacques'a Derridy jednym z ważniejszych tematów jego późnej twórczości. Pytanie o jej możliwość bądź niemożliwość z natury samej rzeczy przybiera postać filozoficznej aporii, gościnność wydarza się zawsze na styku dwóch zupełnie innych światów, jakby na progu domostwa, do którego obcy ma za chwilę wkroczyć. Nie sposób jej zatem nigdy uchwycić, prawdziwa gościnność, najzupełniej bezwarunkowa, jak chciałby ją widzieć Derrida, jest oczekiwaniem nieoczekiwanego — nawet jeśli tym, co ma nadejść, miałaby być przemoc. W innym wypadku — tego, co można nazwać gościnnością warunkową - obcy zostaje przez gospodarza pozbawiony własnej inności, zostaje sprowadzony do roli tymczasowego domownika, który przekroczyć próg może o tyle, o ile zgodzi się stosować do panujących za nim zasad (zob. także. C. Wodziński, Trans gościnności, [w:] idem, Odys gość. Esej o gościnności, Gdańsk 2015, s. 5-25). 
jako odnoszący się do nocy, z której jak najciszej wyjść ma ten, do kogo zwraca się podmiot wiersza. W jakimś sensie przywołana zostaje tutaj również Barańczakowa villanella Ptakała w nocy, ale nie jej płacz go zbudzit; pojawiający się tuż obok zwrot „nie pisz”, niedający się na dobrą sprawę wyjaśnić przez własne otoczenie, chyba że jako zwrot podmiotu do samego siebie, brzmi z kolei jak dalekie echo Tej jednej sztuki Elizabeth Bishop, jak pogłos jej finałowego wersu: „tak, straty to nie takie znów (Pisz!) straszne sprawy”. Obecność Thomasa jest tu oczywista, Suska przepisuje jego tekst na nowo, kładąc nacisk przede wszystkim na wszechobecną pustkę, która zdaje się pochłaniać także i śmierć (noc). Ucieczka od śmierci, wyjście z nocy na światło dzienne, tak przecież pożądane i jako jedyne dające nadzieję na życie, zostają w ostatnim wersie ironicznie podważone („Wyjdź ze stuletnich zetlałych przeźroczy / Na światło dzienne. Cokolwiek to znaczy"). Albo dlatego, że żadna światłość - czy boska, czy ludzka — nie jest w stanie przegnać na dobre „tej okropnej nocy”, albo dlatego, że sam język obnaża tu swoją niewystarczalność, podsuwając poecie brzmiące nieco anachronicznie „stuletnie zetlałe przeźrocza”, cokolwiek one znaczą.

\section{Koda, koniec}

Suska już na początku swojej poetyckiej drogi, której kierunek wyznaczyła fascynacja wszechobecnością śmierci, zwracał uwagę na istnienie „drugiej strony". Niematerialny świat dawał o sobie znać w dużej mierze właśnie poprzez znaki materialnego, fizycznego rozkładu, poprzez nakładanie się na siebie różnych porządków czasowych, sugerujących istnienie innych możliwości oglądu rzeczywistości. Autokomentarz poety do wiersza Światto mógłby równie dobrze dotyczyć zatem całej jego twórczości: „Moja opowieść która miała być konkretną, prostą historią, stała się opowieścią o znikaniu. Zaczęła świecić w inny sposób, innego rodzaju światłem. Tylko, żeby je zobaczyć, trzeba też użyć innego rodzaju oka"32. Widma nawiedzające poezję Suski nie dają mu spokoju, być może dlatego, że spłata zaciągniętego u nich długu - i dotyczy to nie tylko autorów, po których dziedziczy literacką tradycję, ale Innych w ogóle — nie jest możliwa; pojawienie się zjaw, ich wkroczenie w przestrzeń wiersza, rozspójnienie spoiw dotychczas zapewniających poczucie ładu i bezpieczeństwa, oznaczać może nieprzepracowaną żałobę, w przypadku autora Całej w piachu —żałobę po całym świecie. Jeśli Derridowską widmontologię uznać za projekt mający konsekwencje tak metafizyczne, jak etyczne, to niewykluczone, że wiersze Suski należałoby czytać w taki sposób, by nie zapominać o drugim elemencie powyższego wyliczenia. A więc nie odrzucając tego, co istnieje zaledwie mgliście, śladowo: „W życiu, być może nie daje się żyć / bez duchów, bo umysł bo (sic!) podziemny rytm" (Duchy, DD 8).

32 D. Suska, Światto jest wołaniem, [w:] Rozbiórka. Wiersze, rozmowy i portrety 26 poetów, rozmawiała M. Rybak, fotografowała E. Lemmp, Wrocław 2007, s. 170. 


\section{Around the void. Spectres in Dariusz Suska's villanelle}

\section{Summary}

The article presents an attempt of reading the poems of Dariusz Suska with his villanelle taken into particular consideration, in the context of Jacques Derrida's hauntology and the idea of the 'weak thought' by Gianni Vattimo. The key question for the hereby presented interpretation is the issue of inheritance, understood - following Derrida — not as something that we simply inherit, but as a task to accomplish. Spectres haunting Suska remind us that the poet has a debt to pay to a certain generation of spectres (Auden, Bishop, Thomas, Barańczak) - not only does he inherit from them death and fear thereof as the occurring of existence, but also the very villanella. 